Journal of Education and Teaching Learning (JETL)

Vol. 3, No. 1, 28-37 (2020)

Journal Homepage: http://pusdikra-publishing.com/index.php/jetl

\title{
PENERAPAN MODEL PEMBELAJARAN MAKE AMATCH UNTUK MENINGKATKAN KUALITAS PEMBELAJARAN IPS PADA SISWA KELAS VA SDN 106814 TEMBUNG KECAMATAN PERCUT SEI TUAN KABUPATEN DELI SERDANG
}

\author{
Dahman Harahap*)
}

\begin{abstract}
Abstrak
IImu Pengetahuan Sosial adalah bidang studi yang mempelajari, menelaah,menganalisis, gejala dan masalah sosial di masyarakat dengan meninjau dari berbagai aspek kehidupan. Berdasarkan refleksi awal pelaksanaan pembelajaran IPS di kelas VA SDN 106814 Tembung Kecamatan Percut Sei Tuan Kabupaten Deli Serdang menunjukkan bahwa kualitas pembelajaran belum optimal. Hal ini disebabkan adanya beberapa kendala dari guru, siswa dan metode pembelajaran yang digunakan. Kondisi tersebut memerlukan suatu perbaikan pembelajaran yang lebih inovatif dan menarik bagi siswa. Peneliti mengambil solusi untuk melaksanakan PTK menggunakan model make a match. Rumusan masalah penelitian ini adalah apakah model make a dapat meningkatkan keterampilan guru, aktivitas siswa dan hasil belajar siswa. Tujuan dari penelitian ini adalah meningkatkan keterampilan guru, aktivitas siswa, dan hasil belajar IPS siswa kelas VA SDN 106814 Tembung Kecamatan Percut Sei Tuan Kabupaten Deli Serdang.Penelitian yang dilakukan merupakan penelitian tindakan kelas dengan tahapan perencanaan, pelaksanaan tindakan, observasi dan refleksi. Penelitian dilakukan sebanyak 2 siklus dengan 2 kali pertemuan setiap siklus. Subjek penelitian ini adalah guru dan siswa kelas VA SDN 106814 Tembung Kecamatan Percut Sei Tuan Kabupaten Deli Serdang.Hasil belajar siswa pada siklus I mencapai presentase ketuntasan klasikal 60,12 \% dan, kemudian meningkat pada siklus II yaitu presentase ketuntasan klasikal mencapai 75,57 \% dan 85.Berdasarkan hasil penelitian tersebut dapat disimpulkan bahwa model pembelajaran make a match dapat meningkatkan hasil belajar siswa kelas VA SDN 106814 Tembung Kecamatan Percut Sei Tuan Kabupaten Deli Serdang.Saran yang diusulkan peneliti adalah guru hendaknya melakukan pembelajaran yang inovatif dan menarik misalnya dengan menerapkan model pembelajaran make a match ketika mengajar. Selain itu siswa harus dilibatkan secara aktif selama proses belajar mengajar berlangsung.
\end{abstract}

Kata kunci: IPS; Kualitas; Pembelajaran; Make A Match

\section{PENDAHULUAN}

Pendidikan merupakan hal yang sangat penting dalam pembentukan sikap dan kepribadian manusia. Melalui pendidikan, manusia memperoleh ilmu pengetahuan dan pengalaman yang sangat berguna bagi kelangsungan hidupnya.Sebagaimana dijabarkan

\footnotetext{
*) Penulis Adalah Guru SDN 106814 Tembung Kecamatan Percut Sei Tuan Kabupaten Deli Serdang
} 
dalam Undang-undang No 20 tahun 2003 pasal 3 menyebutkan bahwa pendidikan nasional berfungsi untuk mengembangkan kemampuan dan membentuk watak serta peradaban bangsa yang bermartabat dalam rangka mencerdaskan kehidupan bangsa, bertujuan berkembangnya potensi peserta didik agar menjadi manusia yang beriman dan bertakwa kepada Tuhan Yang Maha Esa, berakhlak mulia, sehat, berilmu, cakap, kreatif, mandiri, dan menjadi warga negara yang demokratis serta bertanggung jawab.

Menurut UU Sisdiknas No. 20 tahun 2003 pasal 4 disebutkan bahwa pendidikan diselenggarakan dengan memberi keteladanan, membangun kemauan,dan mengembangkan kreativitas peserta didik dalam proses pembelajaran. Sesuai dengan undang-undang tersebut, seorang guru diharapkan bisa melakukan kegiatan pembelajaran yang bermanfaat bagi siswa. Di sisi lain, pembelajaran sebisa mungkin dilakukan dengan menarik minat dan kemauan siswa agar timbul motivasi dan keinginan untuk belajar dari dalam diri siswa.

Berdasarkan Undang-undang Nomor 20 tahun 2003 pasal 37 ayat 1 menyebutkan bahwa IImu Pengetahuan Sosial merupakan salah satu mata pelajaran wajib pada kurikulum tingkat dasar dan menengah. Ilmu Pengetahuan Sosial adalah bidang studi yang mempelajari, menelaah, menganalisis gejala dan masalah sosial di masyarakat dengan meninjau dari berbagai aspek kehidupan.

Berdasarkan Standar Kompetensi dan Kompetensi Dasar Tingkat SD/MI dalam Peraturan Mentri Pendidikan Nasional Nomor 22 Tahun 2006 tentang Standar isi untuk satuan pendidikan dasar dan menengah bahwa standar kompetensi IPS mengkaji seperangkat peristiwa, fakta, konsep, dan generalisasi yang berkaitan dengan isu sosial. Pada jenjang SD/MI mata pelajaran IPS memuat materi Geografi, Sejarah, Sosiologi, dan Ekonomi.

Tujuan mata pelajaran IPS yang telah tertuang dalam KTSP adalah agar peserta didik memiliki kemampuan sebagai berikut: 1) mengenal konsep-konsep yang berkaitan dengan kehidupan masyarakat dan lingkungannya, 2) memiliki kemampuan dasar untuk berfikir logis dan kritis,rasa ingi tahu, inquiri,memecahkan masalah dan keterampilan dalam kehidupan sosial, 3) memiliki komitmen dan kesadaran terhadap nilai-nilai sosial dan kemanusiaan, 4) memiliki kemampuan berkomunikasi, bekerja sama dan berkompetisi dalam masyarakat yang majemuk ditingkat lokal, nasional dan global. 
Adapun ruang lingkup dari mata pelajaran IPS meliputi aspek-aspek sebagai berikut : (1) manusia, tempat dan lingkungan, (2) waktu, berkelanjutan,dan perubahan, (3) sistem sosial dan budaya, (4) pelaku ekonomi dan kesejahteraan. Penelitian ini difokuskan pada ruang lingkup IPS yang membahas tentang manusia, tempat dan lingkungan yaitu pada K.D Keragaman Suku Bangsa Dan Budaya Di Indonesia.Berdasarkan Naskah Akademik Kajian Kebijakan Kurikulum Mata Pelajaran IPS (2007:6-7) ditemukan bahwa masih banyak permasalahan pelaksanaan standar isi pada mata pelajaran IPS. Dalam hal strategi pembelajaran,penilaian dan sarana pembelajaran. Guru dalam menerapkan metode pembelajaran lebih menekankan pada pada aktivitas guru, bukan pada aktivitas siswa.Pembelajaran yang dilakukan oleh guru kurang variatif. Misalnya guru lebih banyak menggunakan metode ceramah bahkan menyuruh siswa untuk mencatat.Pada aspek penilaian, umumnya guru melakukan penilaian lebih banyak menggunakan alat-alat penilaian yang masih konvensional yaitu tes tertulis. Tes yang digunakan pun masih banyak mengukur aspek kognitif pada jenjang yang lebih rendah misalnya kemampuan untuk menyebutkan.

Materi IPS dipahami sebagai materi yang hapalan saja, sehingga tes yang digunakan pun lebih menekankan pada hapalan. Padahal berbagai keterampilan berpikir dalam IPS bisa diuji melalui penilaian yang dibuat oleh guru. Selain itu, aspek sarana pembelajaran untuk mendukung pembelajaran IPS pada umumnya masih sangat minim.

Beberapa permasalahan tersebut merupakan permasalahan umum dalam pembelajaran IPS. Berdasarkan hasil observasi pada saat kegiatan pembelajaran yang dilaksanakan, peneliti mendapatkan data bahwa dalam kegiatan pembelajaran IPS di kelas V A ditemukan permasalahan, yaitu kegiatan pembelajaran yang kurang optimal. Berbagai faktor penyebab baik dari guru, siswa, maupun sarana dan media pembelajaran juga menjadi kendala dalam proses kegiatan belajar mengajar.

Dalam pelaksanaanya guru masih mendominasi kegiatan belajar mengajar didalam kelas, guru kurang variatif dalam menggunakan model pembelajaran, guru juga sering memberikan tugas kepada siswa dan kemudian meninggalkan kelas. Dalam proses pembelajaran pun, guru tidak membentuk kelompok diskusi antar siswa, sehingga interaksi antar siswa dalam bertukar pendapat masih sangat kurang. Siswa kurang dituntut untuk berpikir kritis dan luas dalam menanggapi masalah yang dikemukakan guru. Sehingga 
siswa memiliki minat dan motivasi belajar yang bisa dikatakan rendah, siswa cenderung pasif dalam kegiatan pembelajaran, siswa kurang percaya diri dalam bertanya, menjawab pertanyaan, dan menyampaikan pendapatnya.

Hal-hal tersebut diatas berdampak pada kurangnya kemampuan siswa dalam memahami konsep mata pelajaran IPS. Hal ini dapat dilihat dari data hasil tes awal siswa yang menunjukkan bahwa sebagian besar siswa belum mencapai nilai kriteria ketuntasan minimal (KKM) yang ditetapkan sekolah.Apabila hal ini dibiarkan berlarut-larut maka siswa akan mengalami kesulitan di dalam menerima materi selanjutnya.Pemecahan masalah mata pelajaran IPS pada siswa kelas VA SDN 106814 Tembung Kecamatan Percut Sei Tuan Kabupaten Deli Serdang adalah peneliti berdiskusi dengan kolaborator untuk memperbaiki kualitas pembelajaran IPS K.D Keragaman Suku Bangsa Dan Budaya Di Indonesia dengan menerapkan model pembelajaran Make a Match.

Model pembelajaran Make A Match pertama kali dikembangkan oleh Lorna Curran pada tahun 1994. Salah satu keunggulan teknik ini adalah siswa mencari pasangan sambil belajar mengenai suatu konsep atau topik dalam suasana yang menyenangkan. Melalui suasana yang menyenangkan diharapkan materi yang akan disampaikan menjadi lebih mudah dipahami siswa, karena bagaimanapun juga siswa terlibat langsung dan mendapatkan pengalaman nyata dalam kegiatan pembelajaran. Dengan demikian proses pembelajaran akan berlangsung dengan lebih variatif dan tidak monoton dengan prinsip membelajarkan, memberdayakan siswa dan bukan mengajar siswa.

Tujuan dari pembelajaran Make A Match ini adalah untuk melatih peserta didik agar lebih cermat dan memperkuat pemahamannya terhadap suatu materi pokok. Model pembelajaran Make A Match saat ini menjadi salah satu strategi penting dalam ruang kelas. Tujuan dari strategi ini antara lain: 1) pendalaman materi; 2) penggalian materi; dan 3) edutainment.

Dalam model pembelajaran ini, siswa dilibatkan secara langsung untuk menemukan pasangan berdasarkan kartu pertanyaan dan kartu jawaban yang diberikan. Jadi siswa bergerak menemukan dan mencocokan sendiri jawaban yang tepat dari kartu pertanyaaan yang diberikan. Dengan proses pembelajaran yang disisipi dengan permainan ini diharapkan siswa menjadi lebih tertarik dan dapat meningkatkan pemahamannya terhadap materi yang diajarkan. 
Berdasarkan uraian di atas, maka peneliti melakukan Penelitian Tindakan Kelas (PTK) dengan judul: "Penerapan Model Pembelajaran Make A Match untuk Meningkatkan Kualitas Pembelajaran IPS pada Siswa Kelas VA SDN 106814 Tembung Kecamatan Percut Sei Tuan Kabupaten Deli Serdang"

\section{METODE PENELITIAN}

\subsection{RANCANGAN PENELITIAN}

Penelitian ini menggunakan jenis Penelitian Tindakan Kelas (PTK).Menurut Aqib, dkk (2014: 3) PTK adalah penelitian yang dilakukan oleh guru di kelasnya sendiri melalui refleksi diri dengan tujuan untuk memperbaiki kinerjanya sehingga hasil belajar siswa meningkat. Menurut Arikunto (2014:58) PTK adalah penelitian tindakan yang dilakukan dengan tujuan memperbaiki mutu praktik pembelajaran di kelasnya.

Jadi dapat disimpulkan bahwa penelitian tindakan kelas adalah penelitian yang dilakukan oleh seorang guru dikelasnya sendiri untuk memperbaiki mutu pembelajaran dan meningkatkan hasil belajar siswa di kelasnya sendiri.Pelaksanaan penelitian tindakan kelas menurut Arikunto (2014:16-19)

meliputi empat tahap yaitu perencanaan, pelaksanaan, observasi, dan refleksi.

\subsection{PERENCANAAN TAHAP PENELITIAN}

Dalam pelaksanaan penelitian ini, peneliti menggunakan dua siklus penelitian, setiap siklus terdiri dari dua pertemuan pembelajaran. Adapun rinciannya sebagai berikut:

\subsubsection{Perencanaan}

a. peneliti dan Observer menelaah SK dan KD yang berhubungan dengan Keragaman Suku Bangsa Dan Budaya Di Indonesia.

b. menyusun Rencana Pelaksanaan Pembelajaran (RPP) dengan materi Keragaman Suku Bangsa Dan Budaya Di Indonesia melalui model make a match.

c. menyiapkan sumber buku dan media pembelajaran kartu pertanyaan-jawaban yang sesuai dengan materi yang akan diajarkan.

d. menyusun alat evaluasi berupa tes tertulis dan LKS. 
e. menyusun lembar observasi untuk mengamati aktivitas siswa dan keterampilan guru.

f. menetapkan kriteria keberhasilan siswa.

\subsubsection{Pelaksanaan Tindakan}

Pelaksanaan tindakan dalam siklus pertama meliputi kegiatan awal,kegiatan inti,dan kegiatan akhir.

a) Kegiatan Awal

a. guru mengkondisikan kelas, mengawali pembelajaran dengan berdoa,mengecek kehadiran siswa dan meminta siswa mempersiapkan buku pelajaran.

b. guru melakukan apersepsi

c. guru menyampaikan tema dan tujuan pembelajaran yang akan dicapai

b) Kegiatan Inti

a. guru menyampaikan indikator yang akan dipelajari pada hari itu, yaitu Keragaman Suku Bangsa Dan Budaya Di Indonesia.

b. siswa diberi kesempatan untuk bertanya kepada guru mengenai materi yang belum jelas.

c. guru menyiapkan satu set kartu pertanyaan dan kartu jawaban yang berkaitan dengan materi.

d. guru memperkenalkan model pembelajaran make a match baru kepada peserta didik

e. guru mengelompokkan kelas menjadi dua kelompok yaitu kelompok $\mathrm{A}$ dan Kelompok B.

f. guru membagikan masing-masing sebuah kartu untuk satu orang siswa.Kartu pertanyaan untuk kelomok $A$ dan kartu jawaban untuk kelompok $B$.

g. siswa mengamati kartu yang diberikan oleh guru.

h. guru menginstruksikan agar siswa yang memegang kartu pertanyaan mencari pasangannya dari kelompok pemegang kartu jawaban.

i. siswa mengerjakan apa yang di instruksikan guru.

j. siswa yang sudah menemukan pasangannya sebelum waktu habis, harus melapor kepada guru. 
k. siswa yang belum menemukan pasangan sampai waktunya habis di minta untuk berkelompok tersendiri.

I. pasangan yang sudah bertemu diberi waktu untuk berdiskusi.

m. siswa mempresentasikan hasil kerja bila diminta oleh guru.

c) Kegiatan Akhir

a. siswa diajak untuk menyimpulkan/merangkum materi yang baru saja diterimanya.

b. siswa mengerjakan soal evaluasi mengenai materi yang telah dipelajari.

c. guru melakukan refleksi.

d. penilaian dan tindak lanjut.

e. guru memberitahukan materi untuk pertemuan selanjutnya supaya dipersiapkan.

f. Guru menutup pelajaran dengan berdoa

\subsubsection{Observasi}

Observasi dalam penelitian ini menggunakan metode observasi langsung,yaitu peneliti dan kolaborator melihat dan mengamati secara langsung kegiatan di dalam kelas kemudian mencatat segala sesuatu yang terjadi selama proses pembelajaran.Adapun aspek yang diamati meliputi:

1. keterampilan guru dalam pembelajaran IPS melalui model Make a Match

2. aktivitas siswa dalam pembelajaran IPS melalui model Make a Match

3. hasil belajar IPS siswa setelah diterapkan model pembelajaran Make a Match

\subsubsection{Refleksi}

Kegiatan refleksi terhadap kegiatan pembelajaran melalui model Make a Match dilaksanakan untuk mengetahui kelebihan dan kekurangan pada siklus kedua. Kegiatan refleksi dalam siklus II

Pertemuan II meliputi:

1. mengkaji pelaksanaan kegiatan pembelajaran dan efek tindakan pada siklus II pertemuan II.

2. mengevaluasi proses dan hasil kegiatan pembelajaran yang telah dilakukan pada siklus II pertemuan II.

3. membuat daftar permasalahan yang terjadi pada siklus II pertemuan II.

4. merencanakan pelaksanaan tindak lanjut jika diperlukan. 


\subsection{SUBJEK PENELITIAN}

Subjek penelitian ini adalah guru dan siswa kelas VA SDN 106814 Tembung Kecamatan Percut Sei Tuan Kabupaten Deli Serdang.Jumlah siswa yang diteliti adalah 32 siswa terdiri dari 7 siswa perempuan dan 25 siswa laki-laki.

\subsection{LOKASI PENELITIAN}

Penelitian ini dilaksanakan di VA SDN 106814 Tembung Kecamatan Percut Sei Tuan Kabupaten Deli Serdang.

\subsection{VARIABEL PENELITIAN}

Variabel penelitian ini adalah:

a. keterampilan guru dalam pembelajaran IPS dengan menerapkan model pembelajaran kooperetif Make a Match.

b. aktivitas siswa dalam pembelajaran IPS dengan menerapkan model pembelajaran kooperetif Make a Match.

c. hasil belajar siswa dalam pembelajaran IPS dengan menerapkan model pembelajaran kooperetif Make a Match.

\section{HASIL DAN PEMBAHASAN PENELITIAN}

\section{A. Data Hasil Penelitian Pada Siklus I danll}

Setelah proses belajar mengajar berlangsung dengan menggunakan metode pembelajaran Make a Match, dilakukan test pada setiap siswa subjek belajar untuk setiap siklus dan diperoleh hasil test setiap siswa. Nilai hasil belajar siswa dapat dilihat pada tabel berikut ini.

Tabel : 4.1 Hasil Test Siklus I

\begin{tabular}{|l|l|l|c|c|}
\hline No & Hasil Tes & Keterangan & Jumlah Siswa & Persentase \\
\hline 1 & Skor $<70$ & Tidak Tuntas & 12 & $36,36 \%$ \\
\hline 2 & Skor $>70$ & Tuntas & 20 & $60,60 \%$ \\
\hline
\end{tabular}

Berdasarkan tabel 4.1.menunjukkan bahwa nilai rata-rata siswa adalah 60,12. 
Perolehan nilai pada siklus I belum sesuai dengan yang diharapkan karena belum mencapai ketuntasan belajar yaitu pembelajaran dikatakan tuntas bila telah mencapai 75 $\%$ jumlah siswa telah mencapai nilai $\geq 70$.

\section{B. Refleksi}

Setelah melihat hasil analisis data hasil belajar siswa pada siklus I dan pengamatan selama proses pembelajaran berlangsung serta melihat aktivitas siswa, maka perlu dilaksanakan pembelajaran pada siklus II dengan melakukan perbaikan desain, cara mengajar, menyampaikan materi. Perolehan nilai pada siklus I belum sesuai dengan yang diharapkan karena belum mencapai ketuntasan belajar, sehingga penelitian tindakan kelas dilanjutkan pada siklus II dimana pembelajaran tetap menggunakan model pembelajaran Make a Match.

\section{Data Hasil Penelitian Pada Siklus II}

Tabel 4.2. Hasil Test (Siklus II)

\begin{tabular}{|l|l|l|c|c|}
\hline No & Hasil Tes & Keterangan & Jumlah Siswa & Persentase \\
\hline 1 & Skor $<70$ & Tidak Tuntas & 5 & $15,15 \%$ \\
\hline 2 & Skor $>70$ & Tuntas & 27 & $81,81 \%$ \\
\hline
\end{tabular}

Berdasarkan tabel 4.2.Menunjukkan bahwa nilai rata-rata siswa adalah 85,57.

Perolehan nilai pada siklus II sudah sesuai dengan yang diharapkan karena telah mencapai $75 \%$ jumlah siswa telah mencapai $\geq 70$, sehingga penelitian tindakan kelas pada siklus II dimana pembelajaran menggunkan metode pembelajaran Make a Match telah dapat mencapai KKM.

Dari tabel di atas dapat dilihat bahwa menggunakan metode pembelajaran Make a Match dapat meningkatkan hasil belajar siswa,dengan demikian berarti tepat bila digunakan model pembelajaran Make a Match pada pokok bahasan Keragaman Suku Bangsa Dan Budaya Di Indonesia pada siswa kelas VA SDN 106814 Tembung Kecamatan Percut Sei Tuan Kabupaten Deli Serdang T.P. 2018/2019. 


\section{SIMPULAN}

Berdasarkan hasil penelitian dan pembahasan, secara umum dapat disimpulkan bahwa:

1. Dalam proses pembelajaran terjadi peningkatan kualitas pembelajaran IPS di VA SDN 106814 Tembung Kecamatan Percut Sei Tuan Kabupaten Deli Serdang, dengan menerapkan model Make a Match.

2. Terjadi peningkatan keterampilan guru dan aktivitas siswa dalam proses pembelajaran IPS dengan menerapkan model Make a Match

3. Terjadi peningkatan hasil belajar siswa dalam pembelajaran IPS yang telah memenuhi criteria ketuntasan minimal yang telah ditetapkan.

\section{DAFTAR PUSTAKA}

Anitah, Sri dkk. 2011. Strategi Pembelajaran SD. Jakarta: Universitas Terbuka.

Arikunto, Suharsimi dkk. 2014. Penelitian Tindakan Kelas. Jakarta: PT Bumi Aksara.

Arsyad, Azhar. 2014. Media Pembelajaran. Jakarta: PT.Rajagrafindo Persada.

Aqib, Zainal. dkk. 2014. Penelitian Tindakan Kelas. Bandung: CV.Yrama Widya.

Hamalik, Oemar. 2012. Proses Belajar Mengajar. Jakarta: Bumi Aksara

Hamdani. 2011. Strategi Belajar Mengajar. Bandung: CV Pustaka Setia.

Harrhyanto, Nar dan HM. Akbid Hamid. 2007. Statistika Dasar.Jakarta: Universitas terbuka.

Huda, Miftahul. 2013. Model-model Pengajaran dan Pembelajaran.Yogyakarta: Pustaka Pelajar.

Rifa'i, Ahmad dan Catharina Tri Anni. 2011. Psikologi Pendidikan.Semarang: Universitas Negeri Semarang.

Rusman. 2014. Model-model Pembelajaran. Bandung: Rajagrafindo Persada.

Sardiman. 2011. Interaksi dan Motivasi Belajar Mengajar. Jakarta: PT Raja Grafindo Persada.

Sudjana, Nana. 2011. Penilaian Hasil Proses Belajar Mengajar.Bandung: Remaja Rosdakarya

Usman, Uzer. 2013. Menjadi guru Profesional. Bandung : Remaja Rosdakarya

Winataputra, Udin S dkk. 2003. Strategi Belajar Mengajar. Jakarta:Universitas Terbuka.

Zaini, M. F. (2017). Hubungan Antara Kompetensi Profesionalisme Dengan Kinerja Guru Di MAN 3 Medan. Tadbir, 1, 19-26. 